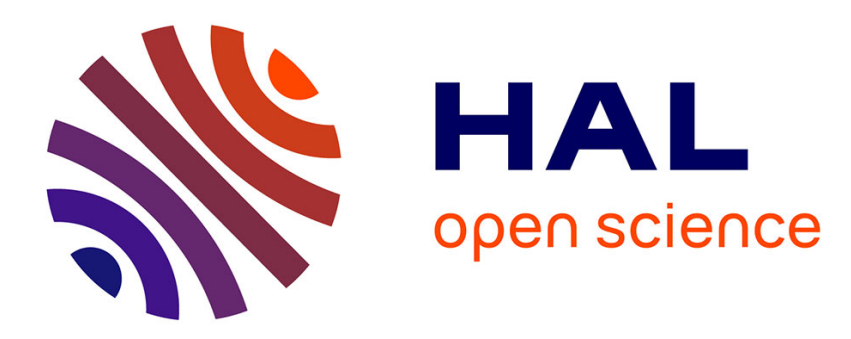

\title{
Mapping urban climate zones and quantifying climate behaviors - An application on Toulouse urban area (France)
}

\author{
Thomas Houet, Grégoire Pigeon
}

\section{To cite this version:}

Thomas Houet, Grégoire Pigeon. Mapping urban climate zones and quantifying climate behaviors - An application on Toulouse urban area (France). Environmental Pollution, 2011, 159 (8-9), pp.2180-2192. 10.1016/j.envpol.2010.12.027 . hal-00561959

\section{HAL Id: hal-00561959 \\ https://hal.science/hal-00561959}

Submitted on 8 Sep 2015

HAL is a multi-disciplinary open access archive for the deposit and dissemination of scientific research documents, whether they are published or not. The documents may come from teaching and research institutions in France or abroad, or from public or private research centers.
L'archive ouverte pluridisciplinaire HAL, est destinée au dépôt et à la diffusion de documents scientifiques de niveau recherche, publiés ou non, émanant des établissements d'enseignement et de recherche français ou étrangers, des laboratoires publics ou privés. 
Provided for non-commercial research and education use. Not for reproduction, distribution or commercial use.

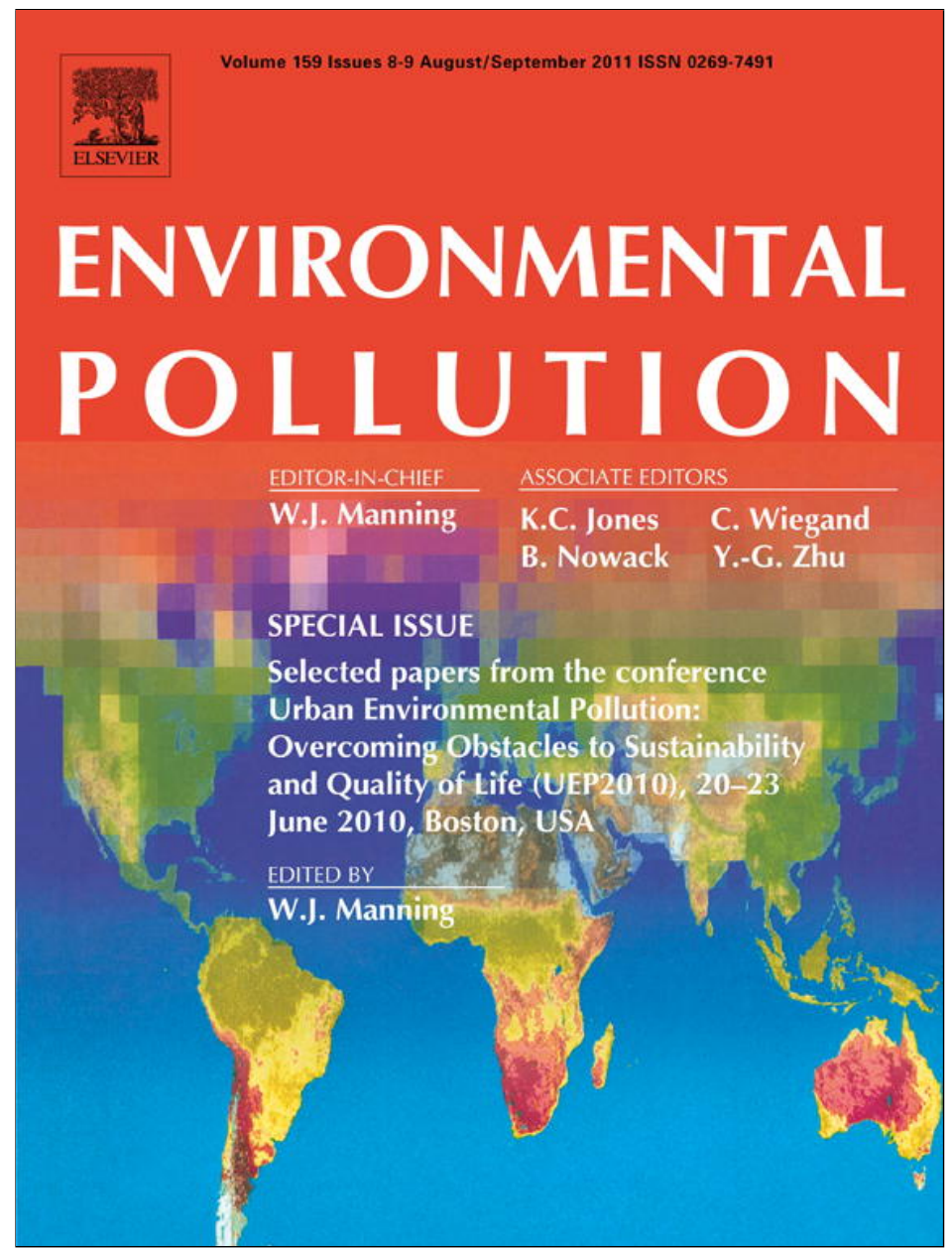

This article appeared in a journal published by Elsevier. The attached copy is furnished to the author for internal non-commercial research and education use, including for instruction at the authors institution and sharing with colleagues.

Other uses, including reproduction and distribution, or selling or licensing copies, or posting to personal, institutional or third party websites are prohibited.

In most cases authors are permitted to post their version of the article (e.g. in Word or Tex form) to their personal website or institutional repository. Authors requiring further information regarding Elsevier's archiving and manuscript policies are encouraged to visit:

http://www.elsevier.com/copyright 


\title{
Mapping urban climate zones and quantifying climate behaviors - An application on Toulouse urban area (France)
}

\author{
Thomas Houet $^{\mathrm{a}, *}$, Grégoire Pigeon ${ }^{\mathrm{b}}$ \\ a GEODE UMR 5602 CNRS, Université de Toulouse, 5 allée Antonio Machado, 31058 Toulouse Cedex, France \\ ${ }^{\mathrm{b}}$ Centre National de Recherches Météorologiques, Météo-France/CNRM-GAME, 42 avenue Coriolis, 31057 Toulouse Cedex, France
}

\section{A R T I C L E I N F O}

\section{Article history:}

Received 28 July 2010

Received in revised form

20 December 2010

Accepted 23 December 2010

\section{Keywords:}

Urban climate zones

Air temperature

Surface temperature

GIS and remote sensing

Urban landscape

Urban heat island

\begin{abstract}
A B S T R A C T
Facing the concern of the population to its environment and to climatic change, city planners are now considering the urban climate in their choices of planning. The use of climatic maps, such Urban Climate Zone-UCZ, is adapted for this kind of application. The objective of this paper is to demonstrate that the UCZ classification, integrated in the World Meteorological Organization guidelines, first can be automatically determined for sample areas and second is meaningful according to climatic variables. The analysis presented is applied on Toulouse urban area (France). Results show first that UCZ differentiate according to air and surface temperature. It has been possible to determine the membership of sample areas to an UCZ using landscape descriptors automatically computed with GIS and remote sensed data. It also emphasizes that climate behavior and magnitude of UCZ may vary from winter to summer. Finally we discuss the influence of climate data and scale of observation on UCZ mapping and climate characterization.
\end{abstract}

(c) 2011 Elsevier Ltd. All rights reserved.

\section{Introduction}

Cities locally modify their own climate (Oke, 1987) mainly by increasing the temperature, a phenomenon called urban heat island (UHI). This climate modification can locally increase the threat generated by heat waves, generally independently of the cities. It is therefore a concern for public health issue (Johnson and Wilson, 2009), energy consumption (Ohashi et al., 2007) and more generally for city administration. It may also influence vegetation phenology (Mimet et al., 2009) and more generally biodiversity.

Currently, the knowledge of the climate inside a city can be developed from observations either in-situ (ground-based, fixed or mobile) or by remotely sensed measurements. Satellite or airborne remote sensing allows a spatially exhaustive monitoring of the climate at the urban/rural interface (Weng and Quattrochi, 2006). Remote sensing is particularly useful for measuring and mapping the surface temperatures that contribute to the modulation of air temperature, and thus determine building thermal ambiance that affects urban comfort (Voogt and Oke, 2003). Surface and air temperatures may differ considerably from each other (Byrne, 1979). The first relates to the temperature of a portion of the

\footnotetext{
* Corresponding author.

E-mail address: thomas.houet@univ-tlse2.fr (T. Houet)
}

Earth's surface that can significantly differ from an adjacent one because of its structure and composition. The air temperature refers to an ambient temperature, resulting from the mixing of the heat fluxes emitted by the surface, the human activities and the background temperature of the surrounding landscape components. However, if current research has demonstrated a strong need to better link surface temperatures and quantitative descriptors (physical properties) of the urban landscape (Voogt and Oke, 2003), there also exists a need to better link climate measurements used to monitor UHI and urban landscapes in order to generate meaningful urban climatic maps than can be used by city planners or public authorities.

For different purposes, scientists have developed landscape classification adapted to urban areas and oriented for climate studies. Urban climate maps can be consider as the first spatially exhaustive and expert-knowledge approach to provide information and planning recommendations that integrate climate factors (Ren et al., 2010). This method combines geographic terrain information, land surface maps (land use /land cover) and analytical climate maps (air temperature, atmospheric humidity, wind direction...) to provide urban climate maps under user-defined scenarios. Such studies were improved by integrating urban morphology (building volume, ground coverage ratio, etc.) ( $\mathrm{Ng}, 2009)$. Others urban climate classifications were defined to highlight urban influence on local climate: Urban Terrain Zones (Ellefsen, 1990); Urban Climate 
Zones (Oke, 2004); Local Climate Zones (Stewart and Oke, 2009a,b, 2010). The interest of these classifications comes from their independence to specific climate conditions. Among these classifications, Oke's UCZ model (2004) is interesting since it is included in the World Meteorological Organization guidelines. This classification identified different Urban Climate Zones (UCZ) based from theoretical divisions of urban terrain based on its ability to modify the local climate. This ability is in turn linked with surface properties like built fraction, roughness class, and aspect ratio, which inherently co-vary with urban landscape structure, land cover, building fabric, metabolism (anthropogenic heat, water and pollution). This classification has been detailed and improved by Stewart and Oke (2009a,b, 2010) throughout the LCZ model (Local Climate Zones) inheriting from Oke's classification. LCZ classification system offers a more detail, generality, and theoretical support. It constitutes the first attempt to differentiate climate zones using observational data. These classifications show some limitations: UCZ identification and derived classifications systems still require an expert-based approach and differences between UCZ climates have not been yet quantified. This paper attempts to answer the challenge to classify urban meteorological stations (Schroeder et al., 2010) based on geographical descriptors.

Thus, based on physical attributes of Oke's UCZ classification (Fig. 1), the main objective of this study is to evaluate if such a classification would be significant to represent at a city scale the location of sensitive climatic areas. In order to be applied, the classification should be possibly automatized using quantitative descriptors of the landscape. Then, it should be significant in terms of climate, i.e. the different classes should show different climate signals based on commonly used climate data for UHI monitoring.

\section{Materials and methods \\ 2.1. Methodological approach}

The area under study is the urban area of Toulouse (France, Lat/Long: $43^{\circ} 36^{\prime} \mathrm{N}-1^{\circ} 26^{\prime} \mathrm{E}$ ). The methodological approach is based on samples surrounding meteorological ground stations of the CAPITOUL (Canopy and Aerosol Particles Interactions in Toulouse Urban Layer) experiment (Masson et al., 2008). CAPITOUL had been conducted between march 2004 and march 2005 in order to better understand energy, water and aerosol particles exchanges between the urban layer and the atmosphere. The climatic variability over the urban area was also assessed

\begin{tabular}{|c|c|c|c|c|}
\hline Urban Climate Zone, UCZ' & Image & $\begin{array}{c}\text { Rough- } \\
\text { ness } \\
\text { class }^{2}\end{array}$ & $\begin{array}{c}\text { Aspect } \\
\text { ratio }\end{array}$ & $\begin{array}{l}\% \text { Built } \\
\text { (imperm- } \\
\text { eable) }\end{array}$ \\
\hline $\begin{array}{l}\text { 1. Intensely developed urban with } \\
\text { detached close-set high-rise } \\
\text { buildings with cladding, e.g. } \\
\text { downtown towers }\end{array}$ & & 8 & $>2$ & $>90$ \\
\hline $\begin{array}{l}\text { 2. Intensely developed high density } \\
\text { urban with } 2-5 \text { storey, attached } \\
\text { or very close-set buildings often } \\
\text { of brick or stone, e.g. old city core }\end{array}$ & & 7 & $1.0-2.5$ & $>85$ \\
\hline $\begin{array}{l}\text { 3. Highly developed, medium } \\
\text { density urban with row or } \\
\text { detached but close-set houses, } \\
\text { stores \& apartments e.g. urban } \\
\text { housing }\end{array}$ & & 7 & $0.5-1.5$ & $70-85$ \\
\hline $\begin{array}{l}\text { 4. Highly developed, low or } \\
\text { medium density urban with large } \\
\text { low buildings \& paved parking, } \\
\text { e.g. shopping mall, warehouses }\end{array}$ & 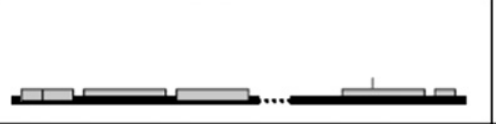 & 5 & $\begin{array}{c}0.05- \\
0.2\end{array}$ & $70-95$ \\
\hline $\begin{array}{l}\text { 5. Medium development, low } \\
\text { density suburban with } 1 \text { or } 2 \\
\text { storey houses, e.g. suburban } \\
\text { housing }\end{array}$ & -G.....A. & 6 & $\begin{array}{l}0.2-0.6 \\
\text { up to }>1 \\
\text { with trees }\end{array}$ & $35-65$ \\
\hline $\begin{array}{l}\text { 6. Mixed use with large buildings in } \\
\text { open landscape, e.g. institutions } \\
\text { such as hospital, university, } \\
\text { airport }\end{array}$ & . & 5 & $\begin{array}{l}0.1-0.5 \\
\text { depends } \\
\text { on trees }\end{array}$ & $<40$ \\
\hline $\begin{array}{l}\text { 7. Semi-rural development, } \\
\text { scattered houses in natural or } \\
\text { agricultural area, e.g. farms, } \\
\text { estates }\end{array}$ & 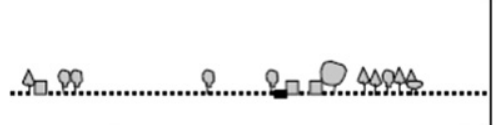 & 4 & $\begin{array}{l}>0.05 \\
\text { depends } \\
\text { on trees }\end{array}$ & $<10$ \\
\hline
\end{tabular}

Key to image symbols: $\square$ buildings; $\$$ vegetation; $\quad$ impervious ground; .....' pervious ground

1 A simplified set of classes that includes aspects of the schemes of Auer (1978) and Ellefsen (1990/91) plus physical measures relating to wind, thermal and moisture controls (columns at right). Approximate correspondence between UCZ and Ellefsen's urban terrain zones is: 1(Dc1, Dc8), 2 (A1-A4, Dc2), 3 (A5, Dc3-5, Do2), 4 (Do1, Do4, Do5), 5 (Do3), 6 (Do6), 7 (none).

2 Effective terrain roughness according to the Davenport classification (Davenport et al., 2000); see Table 2.

${ }^{3}$ Aspect ratio $=Z H W$ is average height of the main roughness elements (buildings, trees) divided by their average spacing, in the city centre this is the street canyon height/width. This measure is known to be related to flow regime types (Oke 1987) and thermal controls (solar shading and longwave screening) (Oke, 1981). Tall trees increase this measure significantly.

${ }_{4}$ Average proportion of ground plan covered by built features (buildings, roads, paved and other impervious areas) the rest of the area is occupied by pervious cover (green space, water and other natural surfaces). Permeability affects the moisture status of the ground and hence humidification and evaporative cooling potential. 
with a 26 air temperature and relative humidity light sensors network located in the streets of the city (Fig. 2). We attempted to identify quantitatively to which UCZ each sample belongs to by using automatically computed GIS-based landscape descriptors. Because the size of the considered samples may influence values of landscape descriptors (e.g. \% of impervious surfaces) and climate processes, we used various sample sizes of 100,250 and $500 \mathrm{~m}$ circle radius for which Oke's descriptors have been be computed. Each sample of climate behavior is characterized using air and surface temperature data based on in situ measurements and remotely sensed imageries.

2.2. Landscape descriptors of Oke's classification based on GIS and remotely sensed data and techniques

Oke's classification of UCZ is based on (1) qualitative descriptors ("images" of urban landform; roughness class - Davenport et al., 2000) and (2) quantitative indices (Aspect ratio and \% impervious surfaces). The first objective is to automatically compute for all samples these landscape descriptors using GIS and remotely sensed data and techniques within $250 \mathrm{~m}$ and $500 \mathrm{~m}$ radius areas.

Images were derived from overlaying building elevation obtained from airborne imagery and photogrammetric techniques and terrain elevation data acquired with ASTER instrument (ASTER DEM $30 \mathrm{~m}$ ). Aspect ratio was derived only considering building elevation (Fig. 3c) within areas of $250 \mathrm{~m}$ and $500 \mathrm{~m}$ radius circle around the Capitoul stations. Considering the urban canyon shape at one particular location (1-D), aspect ratio is calculated dividing the building height by the street width (Nunez and Oke, 1977). Applied to a neighborhood of 100, 200 or 500 m circle radius (2-D), there is not a unique way to compute the aspect ratio given the multiple numbers of streets and also the possible variation of the height of the buildings inside the same street. The choice has been to choose the computation of the aspect ratio adopted in the TEB urban single layer model (Masson, 2000):

$\frac{H}{W}=0.5 \frac{S_{\mathrm{WALL}}}{S_{\mathrm{A}}-S_{\mathrm{BLD}}}$

${ }_{W}^{H}$ is the aspect ratio, $S_{\mathrm{Wall}}$ is the cumulated surface of all walls in the area, $S_{\mathrm{A}}$ is the ground surface of the area and $S_{\mathrm{BLD}}$ is the cumulated ground surface of the buildings. Impervious ratio is derived from a land cover classification. Identification of urban surfaces still remains a challenge because each city shows composition and structure specificities and no universal urban classification method exists (Baklanov et al. 2005). Two kinds of classification methods were tested. Their comparison would be helpful to assess the minimum required resolution of land cover classification to automate Oke's classification. The first is based on an entire SPOT 5 multispectral imagery (acquired in June 2006, $10 \mathrm{~m}$ resolution) using an improved - pixel-based maximum likelihood method using GIS data. Some confusion was removed overlaying building spatial extent as impervious surface on the classification. The second has been developed and applied on 13 sample areas of the 26 Capitoul urban meteorological stations and is based on a multiresolution image clustering (Kurtz et al., 2010). This method is an object-oriented approach using multi-source imageries (color orthorectified aerial photographs acquired in 2004 at $0.5 \mathrm{~m}$ resolution Fig. $3 \mathrm{~b}-$ and SPOT 5 multispectral imagery acquired in June 2004 at $2.5 \mathrm{~m}$ resolution - Fig. 3a). Type of roofs (bright or dark flat roof, typical pink tiles) and other impervious surfaces were more easily differentiated thanks to the spatial resolution. Water surface and vegetation detection was optimized using the near-infra red band of satellite imagery combined with "redness" (typical roof) and "greenness"
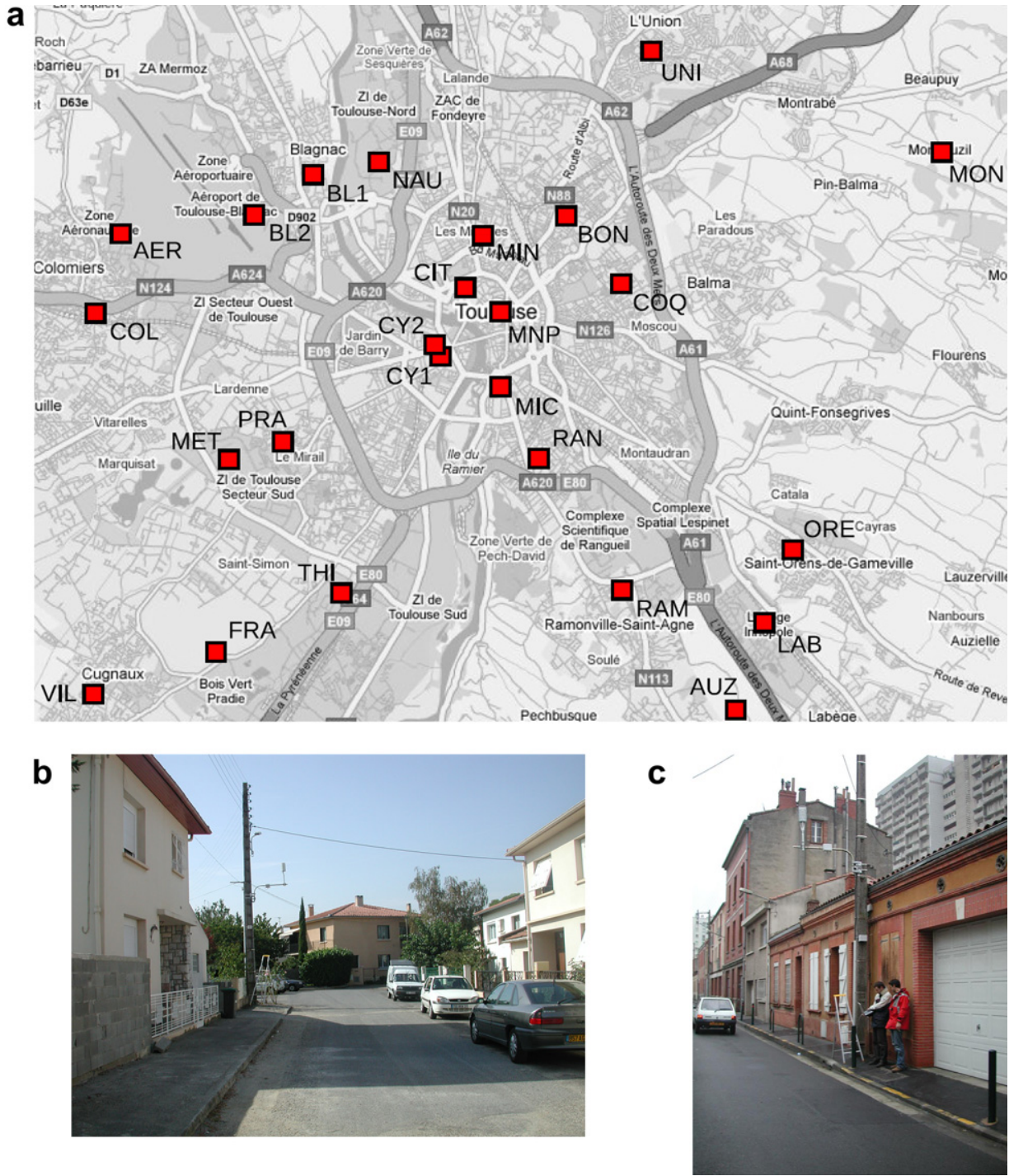

Fig. 2. Map of the network of light meteorological stations measuring air temperature and relative humidity a). Photographs of two sites of the network site COL b) and site CYP c). 
a

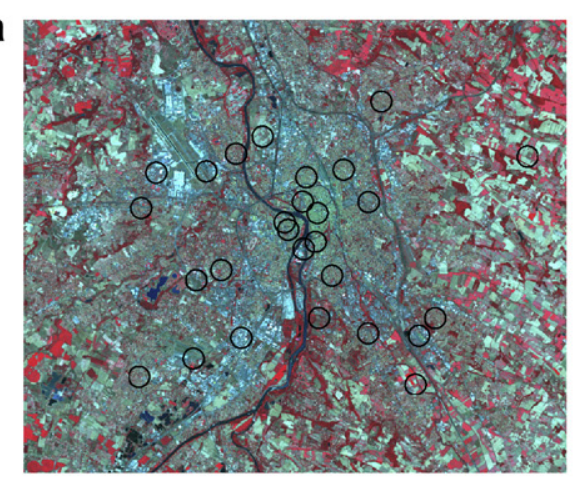

b

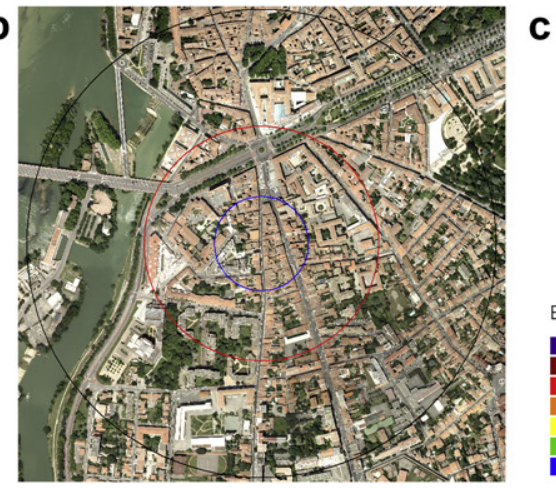

C

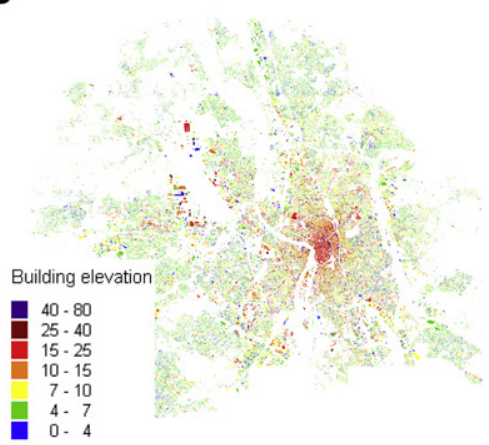

Fig. 3. Description of GIS and remotely sensed data used to compute landscape descriptors. (a) Multispectral Spot 5 imagery - Supermode $2.5 \mathrm{~m}$ - acquired 04/08/11 at 10:43:50 UT; (b) Aerial photographs $(0.5 \mathrm{~m}$ ) on the reference sample (MIC) with areas of $500 \mathrm{~m}$ (black), $250 \mathrm{~m}$ (red) and $100 \mathrm{~m}$ (blue) radius circles; (c) Building elevation data (in meters) (For interpretation of the references to color in this figure legend, the reader is referred to the web version of this article.).

(vegetation and water) indices computed from aerial photographs bands. The classification process is first based on the segmentation of remotely sensed images into homogeneous objects. Each object is affected to a land cover class throughout the definition of rule sets using its features (mean value of NIR, "redness" and "greenness" mean values, length/width ratio, etc.). This classification is spatially limited to the $500 \mathrm{~m}$ radius area.

Roughness has not been calculated because no information exists on vegetation elevation. Mismatch of acquisition dates between satellite imageries have no impact on the classification results because no significant land cover changes occurred within the samples. These descriptors were completed with a description of urban landscape made from in situ observations.

Finally, based on all these landscape descriptors computed from GIS and remotely sensed data, each Capitoul sample was classified according to Oke's UCZ classification thresholds (Fig. 1)

\subsection{Measuring climate behaviors of UCZ based on in situ and remotely sensed data}

The climate at the scale of the city - local and meso scales according to Oke (2006) - has been assessed with two measurements techniques. First, in-situ measurements of air temperature were carried out simultaneously at 26 locations (Fig. 2a) as part of the Capitoul field experiment (Masson et al., 2008). The instruments were placed in locations where air temperature could be representative of a scale larger than the street around the instrument (Oke, 2004). This choice was mainly based on results from Nakamura and Oke (1988) and Eliasson (1996), where both studies focused on the air temperature field inside a canyon. They showed that important gradients exist close to walls or roads but the difference between air temperature above and within the canyon is generally small $\left(<1^{\circ} \mathrm{C}\right)$. Thus, our concern was that the sensors were located way from walls and road surfaces and we therefore positioned these on electrical pylons at $6 \mathrm{~m}$ above the ground. The systems were placed in a radiation shield and set aside from the pylons on a boom of about $1.5 \mathrm{~m}$ (Fig. 2b). The sensors (HygroClip from Rotronic) consisted of a platinum thermistor $(100 \Omega)$. The measurements were logged during a complete year from march 2004 to march 2005 every $12 \mathrm{~min}$. The choice has been made to analyze and compare the daily temperatures maxima and minima rather than synchronous temperatures because these extrema have a higher signification for a larger audience since they are communicated by the medias and weather reports. Of course, in case of a large scale meteorological transition, a large time lag between the maximum or minimum temperature of a station could be observed (Szymanowski, 2005), and the data were not considered. Moreover, the urban heat island develops when the wind and the cloud cover are low and the weather is dry (Kidder and Essenwanger, 1995; Morris et al., 2001; Arnfield, 2003). Consequently only those conditions were selected. For the wind, only the nights (one hour between sunset to one hour after sunrise) with an average wind speed lower than $3 \mathrm{~m} \mathrm{~s}^{-1}$ (Kłysik and Fortuniak, 1999) and with no rain have been selected. To evaluate if clouds were present or not, the atmospheric downward radiation measured at the center of Toulouse during the field campaign has been compared to $0.7 \sigma T_{a}^{4}$ ( $\sigma$ is the Stefan-Boltzmann constant) since this value is a good estimate of this flux in clear sky conditions (Prata, 1996) and only nights when the difference was lower than $50 \mathrm{~W} \mathrm{~m}^{-2}$ were selected. Surface temperatures were derived from three ASTER thermal imageries acquired in summer (Fig. $4-07 / 24 / 2006,08 / 282007$ and 08/30/ 2008). They show an absolute accuracy of 1 to $4 \mathrm{~K}$ and a spatial resolution of $90 \mathrm{~m}$ (Gillespie et al., 1998). The estimated surface temperature data ASTER is one of the most accurate ones compared to other available thermal imageries (Gillespie et al., 2003). The data were converted to Celsius degree and geometrically rectified to be overlaid with other geographical data. Mean surface temperature have been calculated for all Capitoul samples within areas of $100 \mathrm{~m}, 250 \mathrm{~m}$ and $500 \mathrm{~m}$ radius circles.

Two kinds of statistics were computed to characterize climate magnitude of UCZ. The first shows the distribution of the difference in minimum and maximum daily air temperatures between each station and the reference station located in Toulouse downtown (MIC - Fig. 2a) for summer and winter seasons using box plots charts. The second aims to evaluate statistically the climate differences between all the UCZ pairs by pairs. Air temperatures have been compared by seasons for maximum and minimum daily temperature. As an example, for the comparison between the daily minima of UCZ2 and UCZ3 during summer (92 days), the differences between synchronous daily minima of each station of the UCZ2 ( 3 stations) and each station of the UCZ3 (5 stations) have been computed. This results in 15 series of 92 temperature differences. From this dataset, the $95 \%$ confidence intervals for the mean have been computed. The same kinds of analyses have been applied to the surface temperatures. Given that the dataset was reduced to 3 available dates,
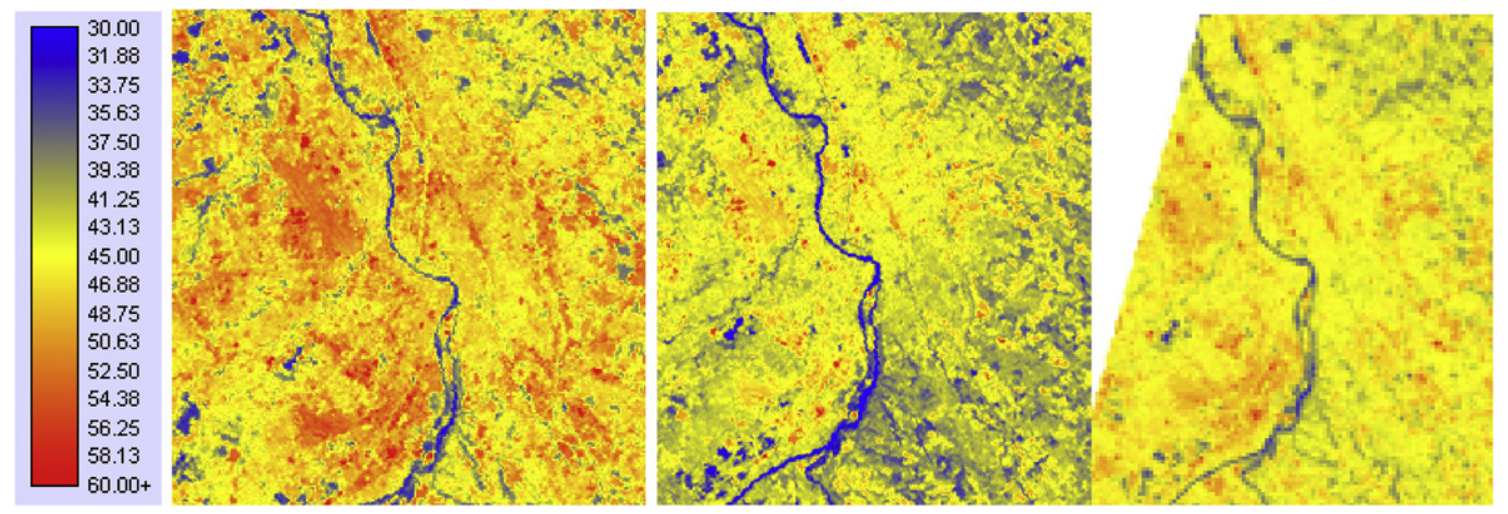

Fig. 4. Temperature data: (a) location of CAPITOUL ground stations measuring air temperature, (b) surface temperature (in Celsius degrees) observed with ASTER on the 07/24/ 2006, 08/28/2007 and 08/30/2008. 


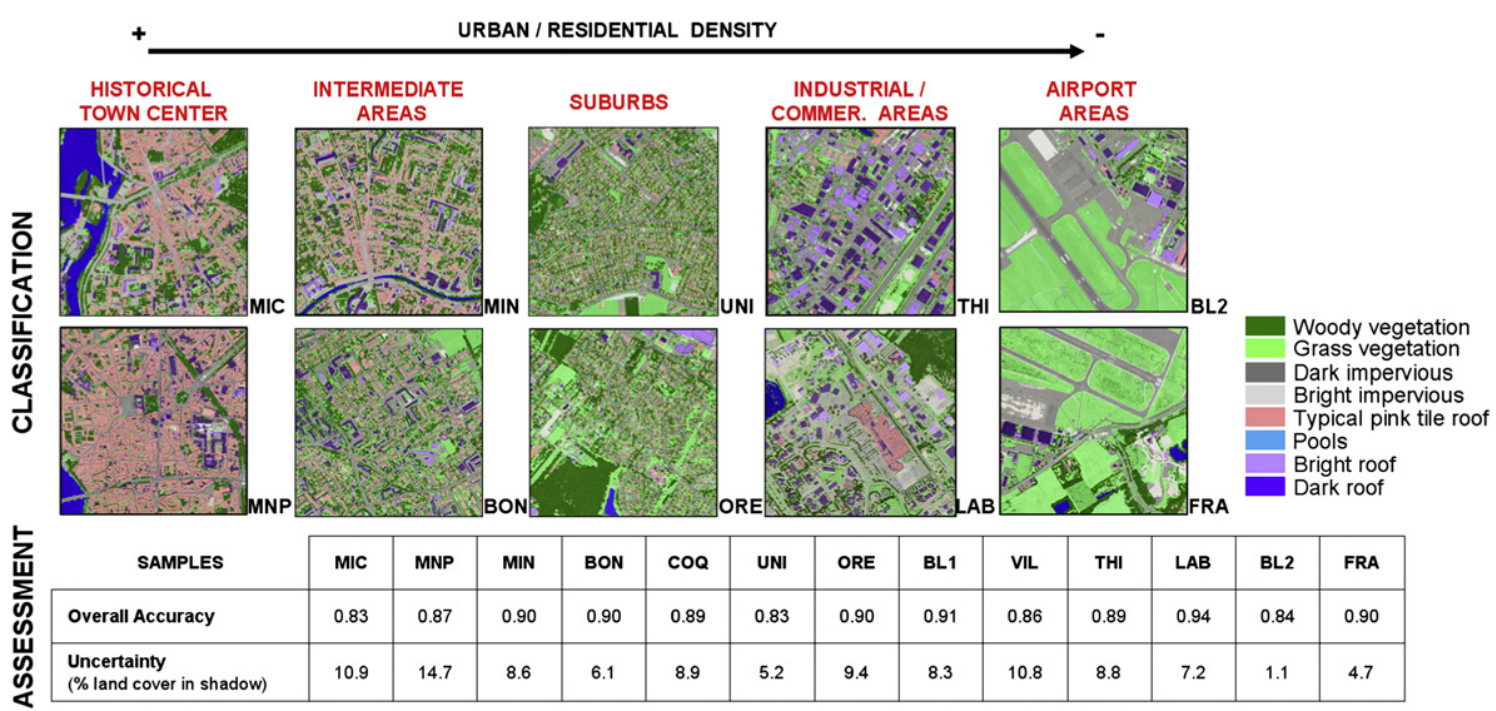

Fig. 5. Results of object-oriented land cover classification.

only the confidence interval for the mean was estimated with a bootstrap method (Efron and Tibshirani, 1993; Leisch, 2007) applied with the R statistical software (R Development Core Team, 2008).

\section{Results}

\subsection{Classification of sites by land cover and urban climate zones}

Results of urban/suburban classifications are shown in Fig. 5. Assessment is made using ground truth observations. Overall accuracy for the samples ranges from 0.83 to 0.94 (Fig. 5).

Because the semi-automatic classification based on maximum likelihood (ML) algorithm has not been evaluated using the overall accuracy or Kappa indices, we first assessed the object-oriented classification against a hand made classification and then compared the impervious fraction of the samples estimated with both classifications. Results (Fig. 6) highlight that semi automatic ML classification tends to over-estimate proportion of impervious surface due to confusion with bare soil.

Finally all landscape descriptors are summarized in Table 1. Some landscape descriptors (aspect ratio, impervious ratio) show lower values than Oke's thresholds. They strongly depend on the urban configuration and composition. For example, MIC sample has an aspect ratio of 0.62 because a large part of the Garonne River is within the $500 \mathrm{~m}$ radius circle. But within the $250 \mathrm{~m}$ radius circle, the value is 0.98 . Some samples exhibit a homogeneous urban landscape (MNP, MIN, THI, UNI, BL2) and perfectly fit Oke's threshold values (respectively for UCZ2, UCZ3, UCZ4, UCZ5 and UCZ6). Some others are more complex to classify due to a mixing of urban landscapes and local specificities (river, park, etc.). The CIT and CY1 samples illustrate a mixed UCZ 2 and 3 but were finally respectively affected to UCZ2 and UCZ3 based on the produced images. But in all cases, landscape descriptors computed for $250 \mathrm{~m}$ radius circle were closer to or perfectly fitted Oke's classification thresholds compared to those computed within $500 \mathrm{~m}$ radius circles.

\subsection{Climate behavior of sample-based UCZ}

\subsubsection{Climate behaviors in winter and summer based} on air temperatures

Results illustrated by Fig. 7 show that the differences are larger for minimum temperatures - the lowest median around $-3^{\circ} \mathrm{C}-$ than for maximum temperatures for which the lowest median is about $-1{ }^{\circ} \mathrm{C}$. This result is quite consistent with most observations acquired in other cities (Arnfield, 2003) reporting that the urban heat island is more intense at night than during the day.

The differences in minimum air temperatures in summer (Fig. 7) show a signal related to the urbanization classes. The stations from the class UCZ2 -red- on the graphics are generally slightly warmer than stations from UCZ3 -orange- on the chart. Both UCZ2 and UCZ3 are sensibly warmer than the stations of UCZ4 -blue- and UCZ5 -yellow- which, finally, are warmer than the UCZ7 -green-. On the other hand, stations from UCZ6 -purple- are harder to separate from the two adjacent classes. Except from the MET site, the distributions of minimum temperatures of the 3 other stations in the class are quite close to those of the UCZ5. The MET station is different from the other stations of its class for both minimum and maximum temperatures in winter (Fig. 7a and b) and summer (Fig. 7c and d). However, the proportion of urban cover (buildings and roads) in a $500 \mathrm{~m}$ radius around the station is much lower

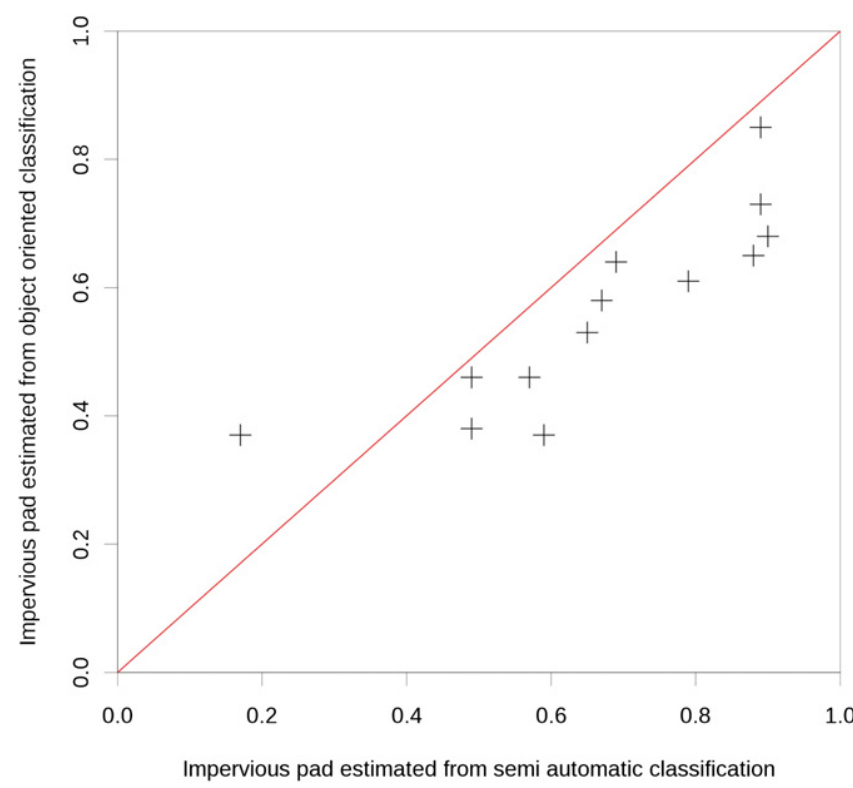

Fig. 6. Comparison of fraction of impervious surfaces obtained from the objectoriented and the semi-automatic (maximum likelihood) classifications. 
T. Houet, G. Pigeon / Environmental Pollution 159 (2011) 2180-2192

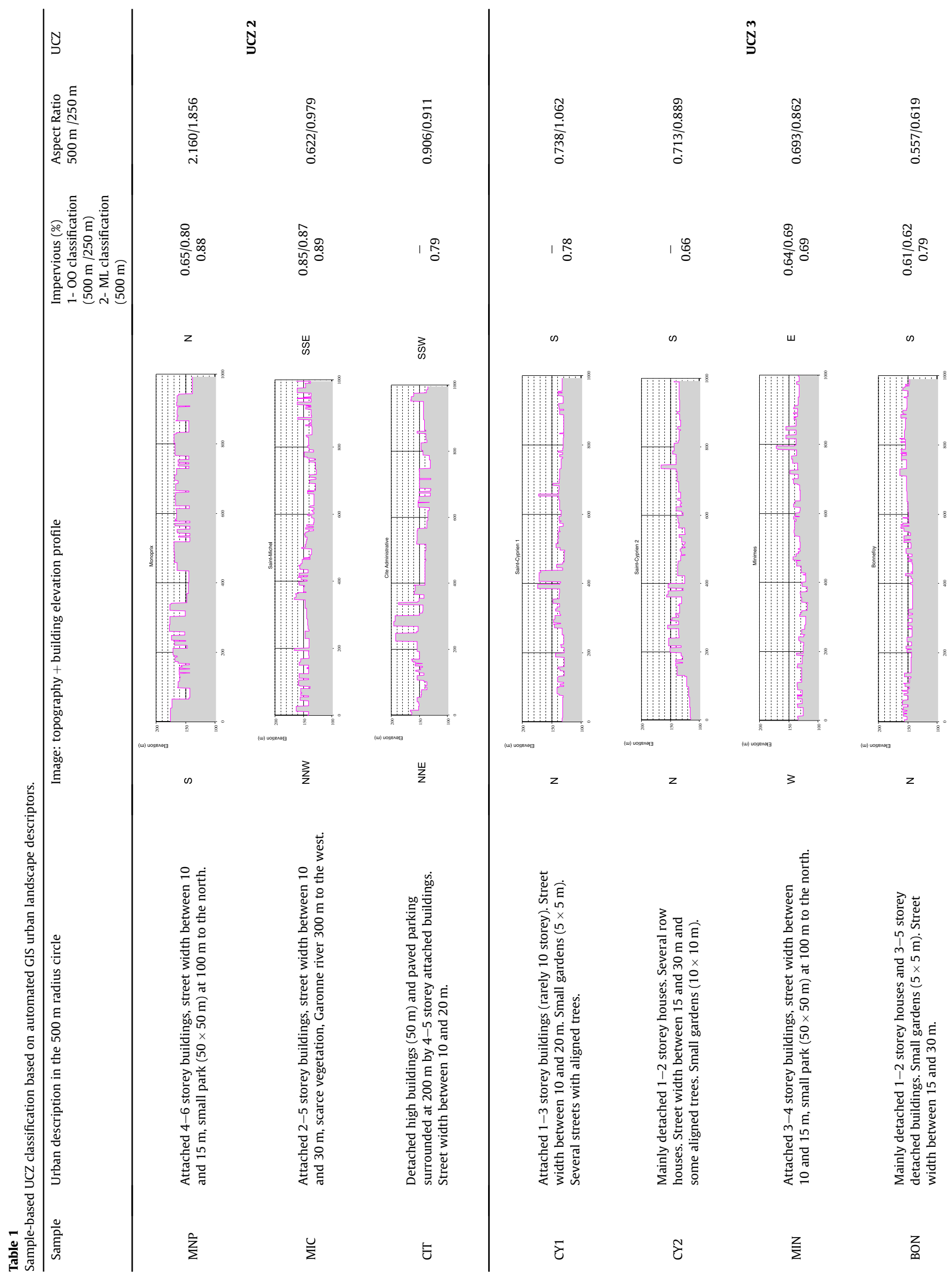




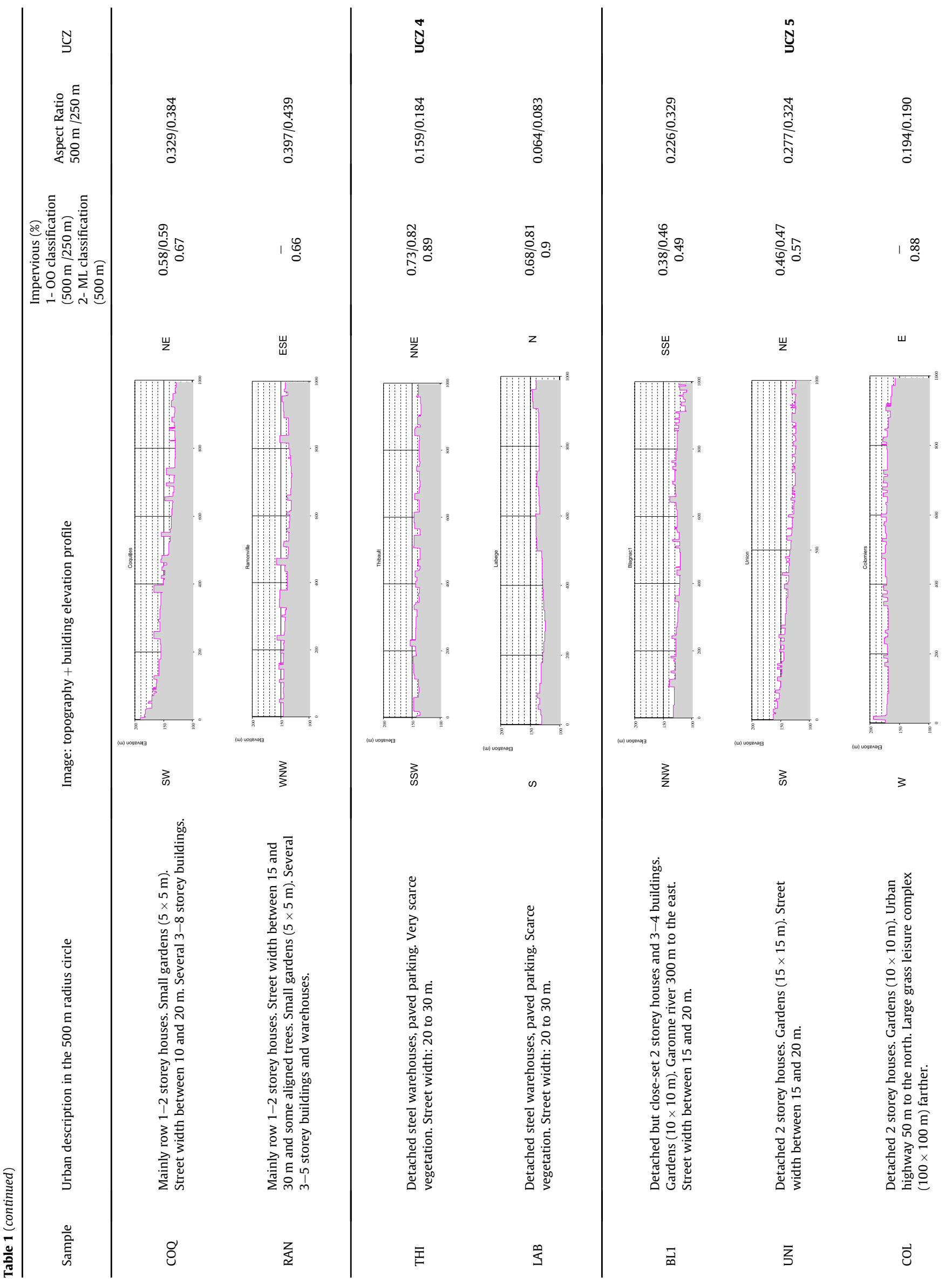




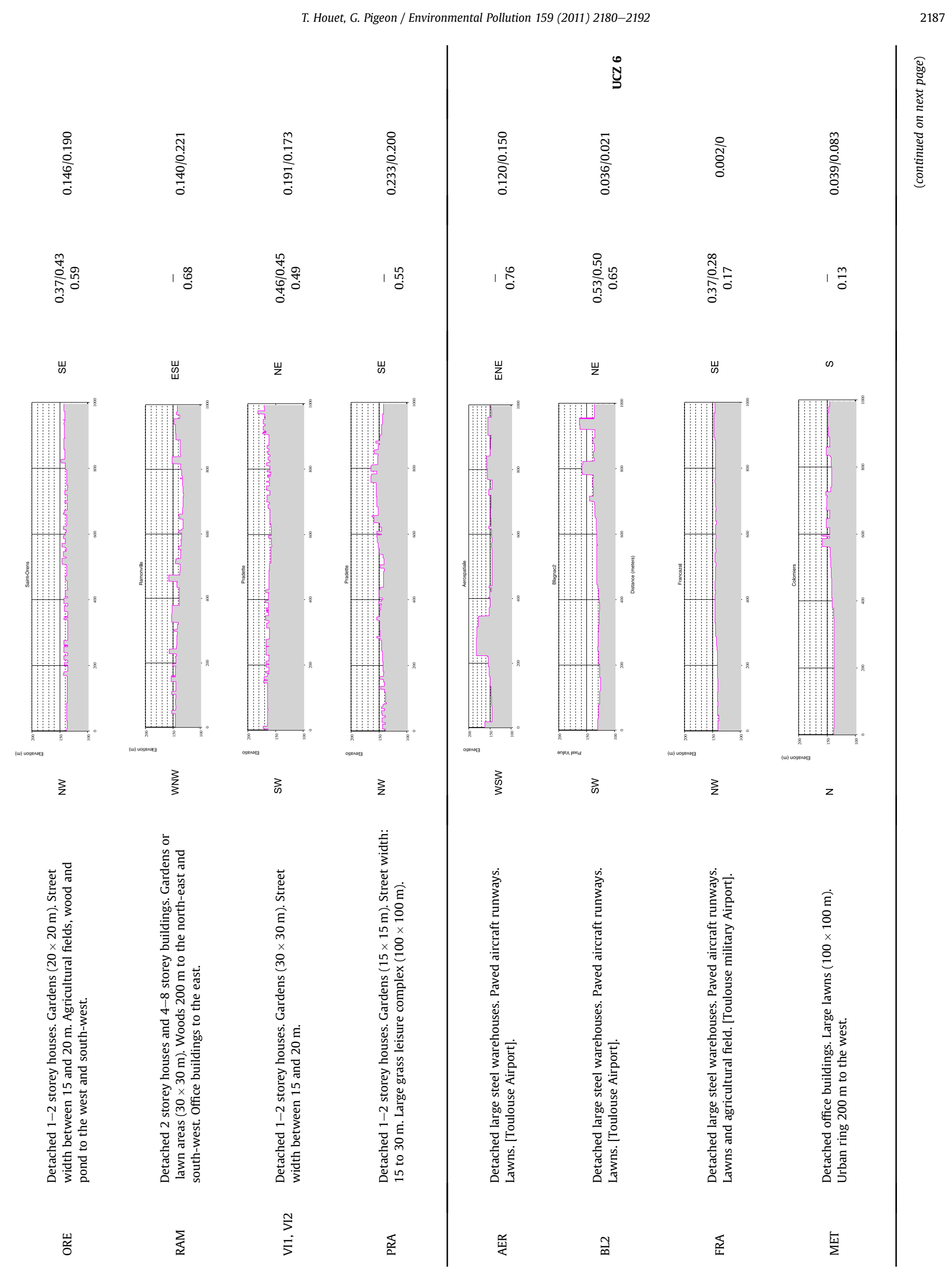




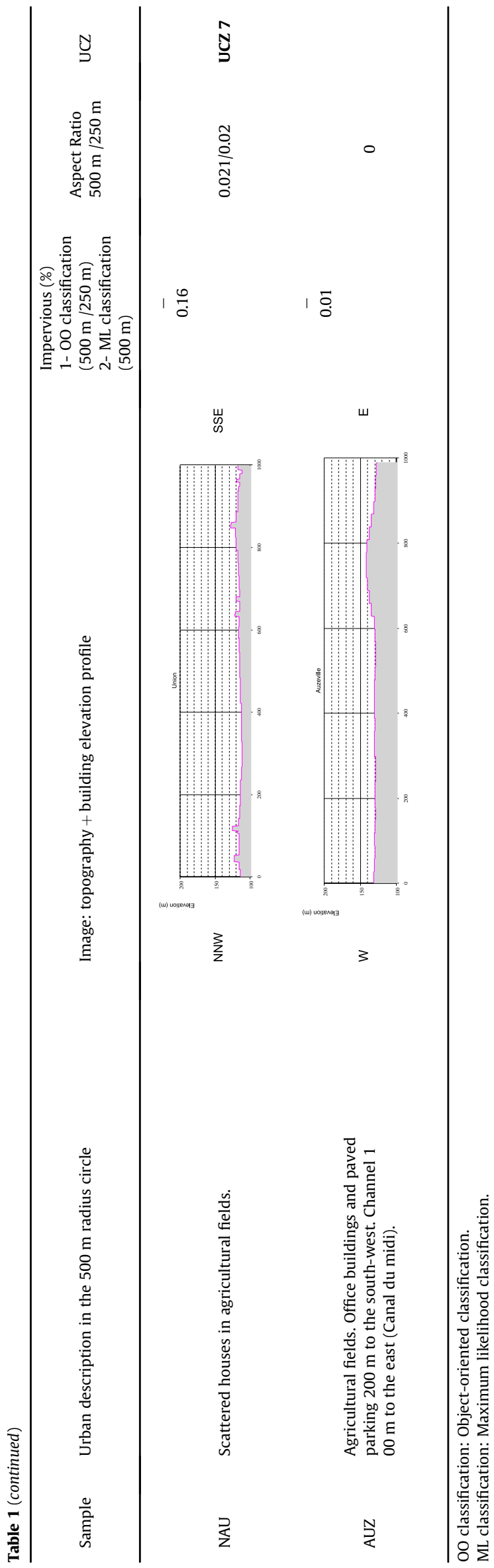

(12\%) than for the other stations $(30-50 \%)$ in the same class (Table 1). The behavior of this station in comparison with the other stations in the same class illustrates the intra-class climate variability. Analysis of the minimum temperature difference distribution in winter (Fig. 7b) leads to the same segmentation as for the summer for stations belonging to classes UCZ2, UCZ3, UCZ4 and UCZ5 although overall the differences are reduced. In addition, there is no separation between the class UCZ5 and the next two classes (UCZ6 and UCZ7).

The segmentation for maximum daily temperature in summer is different (Fig. 7c). The hottest stations (BON, MIN and CYP) are this time from the UCZ3 (orange). The same situation is observed for MIN and CYP stations for maximum daily temperature in winter (Fig. 6a). Then, three classes have sufficiently homogeneous results to be distinguished: classes UCZ2 (red), UCZ5 (yellow) and UCZ7 (green). For the other classes, the internal variability is as great as the differences with other classes and it is more difficult to analyze.

To summarize, urban heat island phenomenon is clearly highlighted by these charts for minimum temperatures in winter and summer. UCZ2 and UCZ3 are approximately +1 to $+2{ }^{\circ} \mathrm{C}$ hotter than surrounding areas in winter or during summer nights. During summer days, maximum temperatures show hotter values (approx. +0.2 to $+0.4^{\circ} \mathrm{C}$ ) in UCZ3 (outskirts) rather than in UCZ2 (historical town centre) and other UCZs.

3.2.2. Climate behaviors in summer based on surface temperatures

As a first result, comparison of climate behaviors of sampled UCZ extracted from surface temperature within a $500 \mathrm{~m}$ radius circle is not appropriate (Fig. 8c). The reference sample exhibits a large amount of water within the studied area which induces an under-estimated mean surface temperature. The climate behaviors of the sampled UCZ are similar within smaller areas ( $100 \mathrm{~m}$ and 250 radius circle). Moreover, the coarser are sample areas, the more uncorrelated are climate behaviors due to an increased variability of surface temperature except for UCZ7.

In the Fig. $8 \mathrm{a}$ and $\mathrm{b}$, the climate behaviors during the day in summer are quite similar to those observed with air temperature. UCZ3 appears warmer and UCZ4 slightly cooler than UCZ2. On the other hand, UCZ4 and UCZ6 exhibit surface temperature +4 to +6 Celsius degrees above those of MIC reference sample. The types of building of industrial/commercial area (building materials) and land use (airport) may explain these differences. But these UCZ4 and UCZ7 behaviors significantly differ from those observed with air temperature. This could be explained by the fact that they do not contribute to warm ambient temperature during the day and most of solar radiation is transmitted rather than emitted. Another assumption that concerns UCZ4 is that the acquired air temperature is not representative of higher temperature resulting from the mix of hot surface temperature of roofs and ambient temperature. Finally, the larger sample is the sample area, the more variable are surface temperatures.

\subsubsection{Climate differences between $U C Z$}

The pair differences between UCZ are presented in Tables 2-4. In each matrix, the upper part of the diagonal refers to winter period (December, January and February) while the other part is for the summer period (June, July and August) except for the surface temperature $\left(T_{\mathrm{S}}\right)$, for which only the summer period was available. In the upper part of the matrix, the differences should be read between the UCZ in row and the UCZ in column whereas it is the column minus the row for the lower part so that we could compare directly both sides of the diagonal.

From these matrixes, it can be noted that there is always a season and a parameter for which there is a significant difference between each UCZ pair. Concerning the air temperature, the 

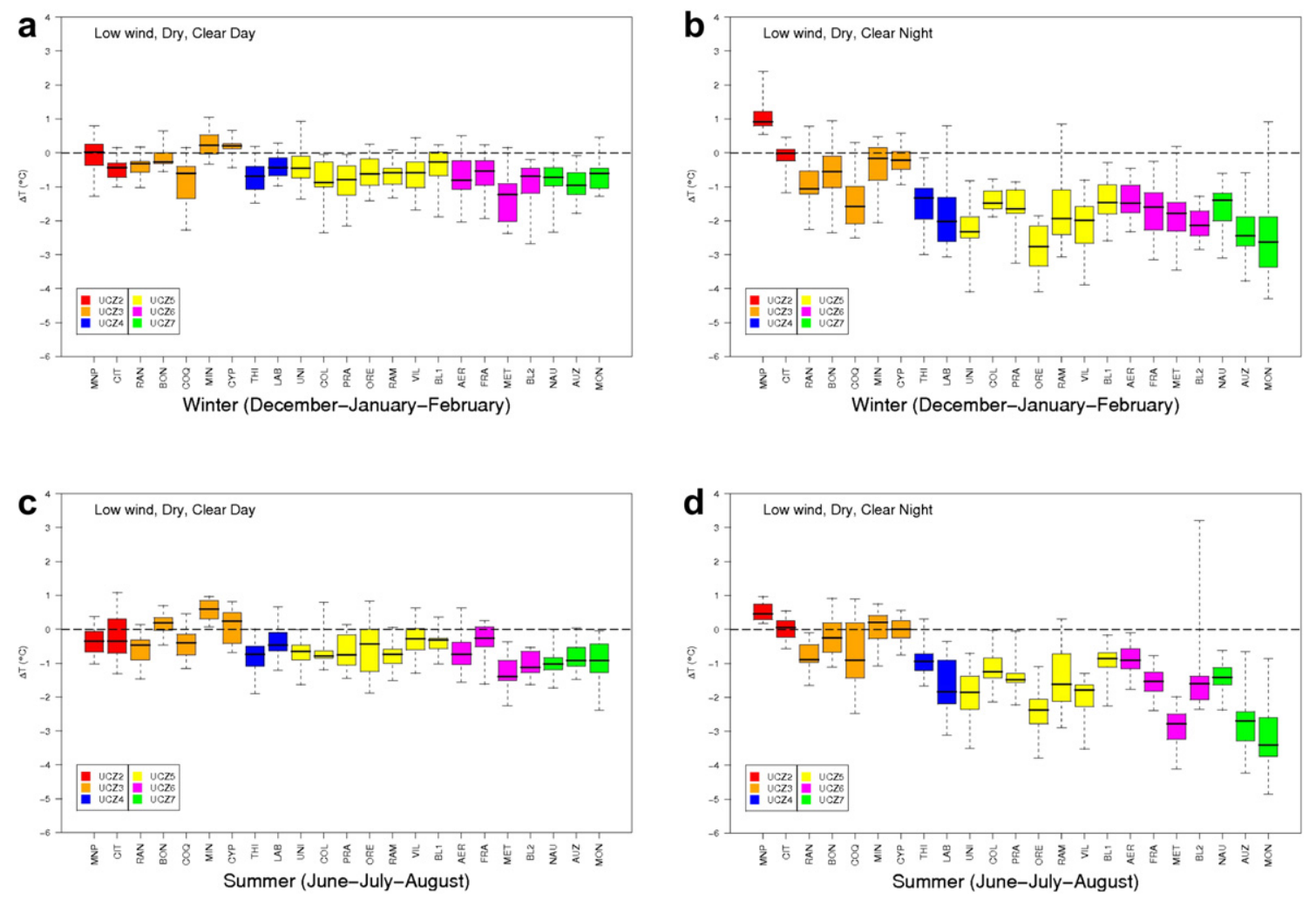

Fig. 7. Distribution of the air temperature difference with the UCZ2 MIC station. Differences of daily maximum temperature in (a) winter and (c) summer. Differences of daily minimum temperatures in (b) winter and (d) summer.

difference is on average $1{ }^{\circ} \mathrm{C}$ higher between the minimum daily temperatures $\left(T_{\mathrm{N}}\right)$ than between the maximum ones $\left(T_{\mathrm{X}}\right)$.

A more precise analysis shows that a few pairs do not present a significant difference for $T_{\mathrm{N}}$ or $T_{\mathrm{X}}$ during one of the two seasons. For example, considering the minimum temperature during winter, there is no significant difference between UCZ4, UCZ5, UCZ6 and UCZ7 for which 0 is included in the confidence interval of the difference. On the contrary, for the same parameter but during summer, there are always small but significant differences within the same UCZ except for UCZ5 and UCZ6. Still comparing the daily minimum, the differences between UCZ2, UCZ3 and UCZ4 are 0.4 to $0.5^{\circ} \mathrm{C}$ stronger during winter than during summer whereas this is not the case for other classes nor for the daily maximum temperature. Concerning the differences between daily maxima the behavior of UCZ3 during summer can be emphasized since it is the hottest class. It is $0.4{ }^{\circ} \mathrm{C}$ hotter than the UCZ2 which is the most urbanized class present in Toulouse. These results refine and validate those estimated in section 3.2.1.

Finally, analysis of the surface temperature ( $100 \mathrm{~m}$ around the sites) dataset shows that there is a larger variability for this parameter so that there are more pairs of classes for which the difference of temperature is not significant ( 0 inside the confidence interval). On another hand, differences of UCZ4 and UCZ6 with the other classes are significant and in the opposite direction of the differences for the air temperature.

\section{Discussion}

\subsection{Different climate behaviors of residential areas in winter and summer}

The observation of warmer maximum daily temperature for UCZ3 during summer is original and not reflected in the literature.
These stations have a fraction of urbanization usually between 60 and $70 \%$ (Table 1) against $80-90 \%$ for the stations from the UCZ2 class. Thus the variation of this indicator between these two classes goes against what is seen for the variation of the daily maximum temperature. Variation of the aspect ratio between the two classes can be related with this climatic parameter. The streets of the downtown of Toulouse corresponding to the UCZ2 class are narrow - typically between 10 and $20 \mathrm{~m}$ - the height of the buildings is between 15 and $20 \mathrm{~m}$ while in the area of the UCZ3 sites, which are the ancient suburbs of the city and now almost considered to be part of the center area of Toulouse, the height of buildings is around $7 \mathrm{~m}$ with a similar width for the streets as for UCZ2. Thus the aspect ratio is higher for the UCZ2 sites, with values between 1 and 2, than for the UCZ3 with values from 0.3 to 1 (Table 1 ). Consequently, our hypothesis is that the solar penetration is enhanced in UCZ3 areas compared with UCZ2. This leads to a larger fraction of the surface that is sunlit, higher sensible heat fluxes and higher air temperature when it reaches its maximum. On another hand, during the cooling period, the UCZ3 areas can have a higher cooling rate since the sky view factor is higher.

The comparison of the minimum daily temperature between winter and summer is also original. The behavior of UCZ2, UCZ3 and UCZ4 is specific with higher differences between themselves during winter than during summer. The same kind of behavior is not observed with the other classes neither in the literature. Our hypothesis is that it could be related with the anthropogenic heat releases which are stronger during winter in UCZ2 areas (between 50 and $100 \mathrm{~W} \mathrm{~m}^{-2}$ ) than respectively UCZ3 (between 25 and $50 \mathrm{~W} \mathrm{~m}^{-2}$ ) and then UCZ4 (between 5 and $25 \mathrm{~W} \mathrm{~m}^{-2}$ ) (Pigeon et al., 2007). The higher differences between these three classes and the others during summer may be due to other processes such as the partition between latent and sensible heat fluxes related to the vegetation. 

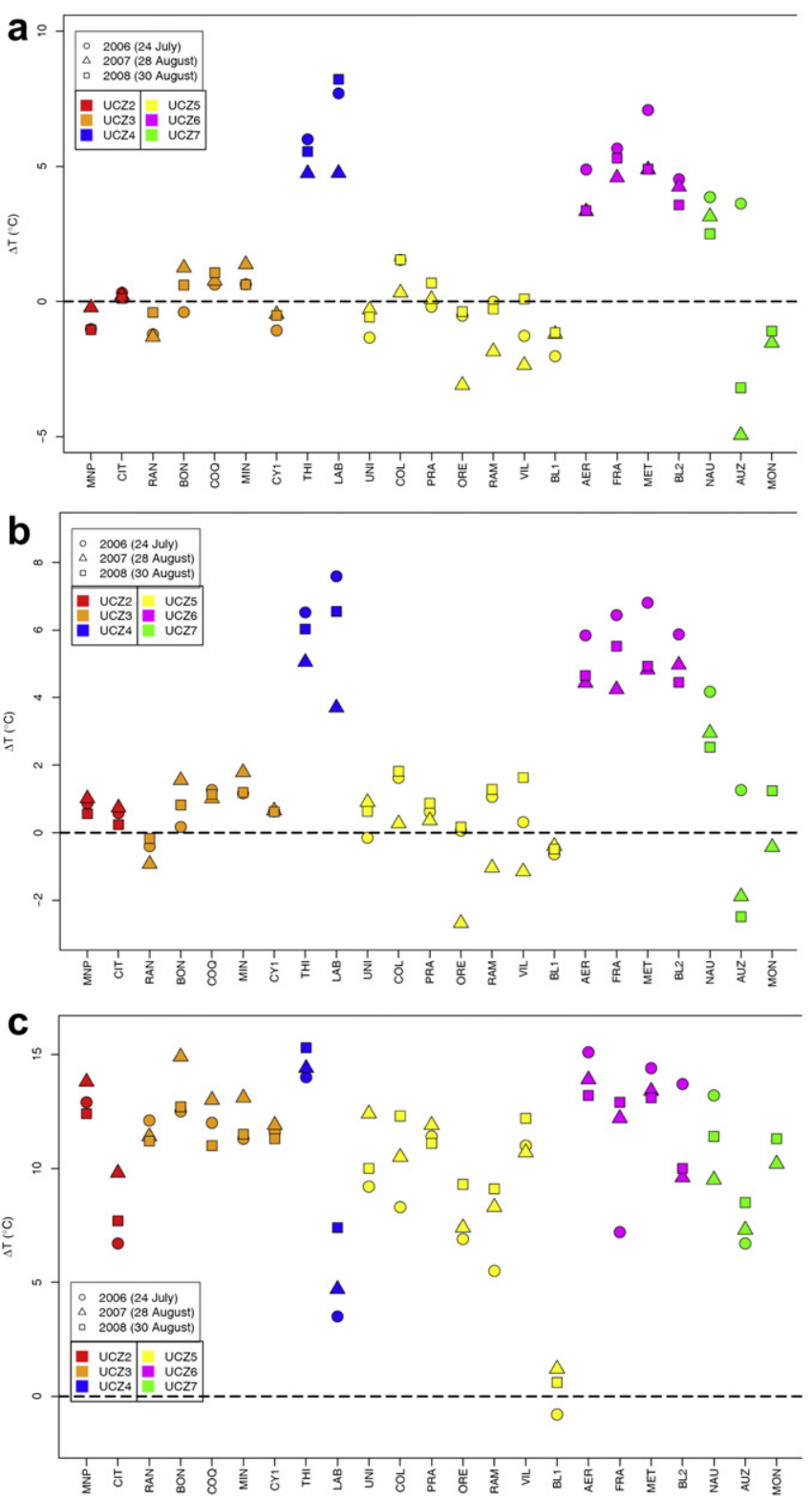

Fig. 8. Distribution of the surface temperature difference between the UCZ2 MIC station and each other station (a) within the $100 \mathrm{~m}$, (b) the $250 \mathrm{~m}$ and (c) $500 \mathrm{~m}$ radius circle around stations.

\subsection{Influence of climate data on the determination} of UCZ climate behaviors

Surface temperatures have been measured during summer at 11.00 UTC, so they can be compared with the daily maximum air temperature during the same season. The first difference between the two dataset is about the variability of the differences between UCZ (Tables 2-4, Figs. 7 and 8). There are more pairs of UCZ for which the difference is not significant at $95 \%$ for the surface temperature than for the air temperature because 0 is inside the confidence interval such as, for example, differences between UCZ2 and UCZ3, UCZ2 and UCZ5 or UCZ2 and UCZ7. This can be due to the fact that the dataset is smaller in comparison with data available for air temperature (92 dates versus 3 dates). But this can be due to a higher variability when the surface temperature is estimated from $100 \mathrm{~m}$ radius circles to $500 \mathrm{~m}$.

However, significantly diverging behaviors are observed for UCZ4 and UCZ6. Their surface temperature is higher $\left(+5{ }^{\circ} \mathrm{C}\right)$ (Table 4) compared to those of UCZ2. First, these differences are opposite to what is recorded for air temperature and second, the absolute values are higher. It is an important remark for users that would be interested by using surface temperature to monitor the urban climate and this result could be related to the results of Roth et al. (1989) who explained that surface temperatures measured from satellite with a nadir view are more influenced by the type of roofs which have a stronger thermal variability than the other elements of the urban surface such as the walls. Another hypothesis that could be combined with the previous one is based on the proportion of asphalt which is similar for these two UCZ. Better linking of air and surface temperatures could be enforced more specifically on these UCZ where climate data strongly influence UCZ climate behaviors.

On the other side, some common climate behaviors of UCZ can be observed with both air and surface temperature. Results show that UCZ3 tend to be warmer than UCZ2 in summer which both remains also warmer than residential suburbs. Of course, magnitudes of UCZ climate difference are adapted for Toulouse urban area and these results should be compared to others cities.

\subsection{Towards a spatially exhaustive UCZ mapping to monitor UHI}

Computation of landscape descriptors has been applied for specific areas located around existing ground stations. A future work to consider is to produce a spatially exhaustive map of UCZ. Indeed, based on obtained results, such a map combined with reference ground station and/or thermal satellite imageries would be very useful to monitor winter and summer UHI during extreme events. This map could be produced using a regular grid applied over urban area. Because impervious and aspect ratio values may vary considering the resolution of the grid, the size of grid cells should be finer than the $500 \mathrm{~m}$ radius circle of influence for air temperature mentioned by Oke (2004). The identifying optimum grid resolution is a key issue to conveniently consider both air and surface temperature data. Even more, overlaying a grid on an urban area to produce a UCZ map will encounter problems because the irregular UCZ boundaries will not follow the regular intervals of the grid. A grid resolution of $100-200 \mathrm{~m}$ or less is therefore needed to best portray UCZs onto

Table 2

Average differences between pairs of UCZ and 95\% confidence interval band for minimum daily air temperature. Values above diagonal are for winter and differences equal UCZ in row minus UCZ in column. Values below the diagonal are for summer and differences equal UCZ in column minus UCZ in row.

\begin{tabular}{|c|c|c|c|c|c|c|c|}
\hline \multirow{3}{*}{$\begin{array}{l}\text { Mean }\left(\Delta T_{\mathrm{N}}\right) \\
\begin{array}{l}T_{\mathrm{N}} \text { summer (difference } \\
\text { column }- \text { row })\end{array}\end{array}$} & \multicolumn{7}{|c|}{$T_{\mathrm{N}}$ winter (difference row - column) } \\
\hline & & UCZ 2 & UCZ 3 & UCZ 4 & UCZ 5 & UCZ 6 & UCZ 7 \\
\hline & UCZ 2 & & $0.9 \pm 0.2$ & $1.9 \pm 0.5$ & $2.1 \pm 0.3$ & $2.0 \pm 0.3$ & $2.4 \pm 0.5$ \\
\hline & UCZ 3 & $0.5 \pm 0.2$ & & $0.8 \pm 0.4$ & $1.2 \pm 0.2$ & $1.1 \pm 0.2$ & $1.3 \pm 0.4$ \\
\hline & UCZ 4 & $1.4 \pm 0.3$ & $1.0 \pm 0.2$ & & $0.3 \pm 0.4$ & $0.1 \pm 0.4$ & $0.5 \pm 0.6$ \\
\hline & UCZ 5 & $1.7 \pm 0.2$ & $1.3 \pm 0.1$ & $0.3 \pm 0.2$ & & $0.0 \pm 0.2$ & $0.2 \pm 0.3$ \\
\hline & UCZ 6 & $1.9 \pm 0.2$ & $1.4 \pm 0.2$ & $0.4 \pm 0.3$ & $0.1 \pm 0.2$ & & $0.3 \pm 0.4$ \\
\hline & UCZ 7 & $2.6 \pm 0.3$ & $2.1 \pm 0.3$ & $1.1 \pm 0.3$ & $0.8 \pm 0.2$ & $0.7 \pm 0.3$ & \\
\hline
\end{tabular}


Table 3

Same as Table 2 but for the daily maximum air temperature.

\begin{tabular}{|c|c|c|c|c|c|c|c|}
\hline \multirow{3}{*}{$\begin{array}{l}\text { Mean }\left(\Delta T_{\mathrm{X}}\right) \\
T_{\mathrm{X}} \text { summer (difference } \\
\text { column }- \text { row) }\end{array}$} & \multicolumn{7}{|c|}{$T_{\mathrm{X}}$ winter (difference row - column) } \\
\hline & & UCZ 2 & UCZ 3 & UCZ 4 & UCZ 5 & UCZ 6 & UCZ 7 \\
\hline & UCZ 2 & & $0.0 \pm 0.2$ & $0.5 \pm 0.3$ & $0.4 \pm 0.1$ & $0.7 \pm 0.2$ & $0.6 \pm 0.2$ \\
\hline & UCZ 3 & $-0.4 \pm 0.6$ & & $0.4 \pm 0.3$ & $0.4 \pm 0.1$ & $0.6 \pm 0.2$ & $0.6 \pm 0.2$ \\
\hline & UCZ 4 & $0.1 \pm 0.9$ & $0.5 \pm 0.3$ & & $0.0 \pm 0.2$ & $0.3 \pm 0.3$ & $0.2 \pm 0.3$ \\
\hline & UCZ 5 & $0.1 \pm 0.5$ & $0.5 \pm 0.1$ & $0.0 \pm 0.1$ & & $0.2 \pm 0.2$ & $0.2 \pm 0.2$ \\
\hline & UCZ 6 & $0.6 \pm 0.8$ & $0.9 \pm 0.4$ & $0.4 \pm 0.7$ & $0.4 \pm 0.4$ & & $0.0 \pm 0.2$ \\
\hline & UCZ 7 & $0.4 \pm 0.7$ & $0.9 \pm 0.2$ & $0.3 \pm 0.2$ & $0.3 \pm 0.1$ & $-0.1 \pm 0.5$ & \\
\hline
\end{tabular}

Table 4

Same as Table 2 but for the summer time surface temperature at 11.00 UTC.

\begin{tabular}{|c|c|c|c|c|c|c|c|}
\hline \multicolumn{8}{|l|}{$\operatorname{Mean}\left(\Delta T_{\mathrm{S}}\right)$} \\
\hline $\begin{array}{l}T_{\mathrm{S}} \text { summer (difference } \\
\text { column - row) }\end{array}$ & UCZ 2 & UCZ 2 & UCZ 3 & UCZ 4 & UCZ 5 & UCZ 6 & UCZ 7 \\
\hline & UCZ 3 & $-0.5 \pm 0.6$ & & & & & \\
\hline & UCZ 4 & $-4.8 \pm 1.9$ & $-4.3 \pm 1.8$ & & & & \\
\hline & UCZ 5 & $0.4 \pm 0.7$ & $0.9 \pm 0.6$ & $5.2 \pm 1.3$ & & & \\
\hline & UCZ 6 & $-4.9 \pm 0.8$ & $-4.4 \pm 0.8$ & $-0.1 \pm 1.7$ & $-5.3 \pm 0.7$ & & \\
\hline & UCZ 7 & $0.1 \pm 2.0$ & $0.5 \pm 1.8$ & $4.8 \pm 2.4$ & $-0.3 \pm 1.3$ & $4.8 \pm 1.6$ & \\
\hline
\end{tabular}

a city map. Multi-scaled moving windows techniques used in landscape ecology (Gustafson, 1998; Wu et al., 2002; Gaucherel, 2007) appear very appropriate for such urban climate application.

A spatially exhaustive map of UCZ would be helpful for several reasons. First, it would localize urban areas concerned by different climate behavior over seasons and be a good indicator of urban climate variability. Second, when overlaid with a land cover map, this UCZ map may contribute to identify possible urban management strategies to reduce heat wave effects in cities.

\section{Conclusion}

This paper shows first that it has been possible to pass through expert-based approach in order to determine the assignation of sample areas to an UCZ. Quantified landscape descriptors have been automatically computed based on GIS and remote sensed data and techniques. Secondly, it emphasizes the climate behavior and magnitude of UCZ which are varying over seasons and locations. Thus in winter, the Toulouse town center could be respectively from $0.5 \pm 0.1^{\circ} \mathrm{C}$ to $1.1 \pm 0.1^{\circ} \mathrm{C}$ warmer than the suburbs on average for daily minimum air temperatures to $1.4 \pm 0.3^{\circ} \mathrm{C}$ to $2.5 \pm 0.4{ }^{\circ} \mathrm{C}$ for extreme events (90\% quantile). In summer, historical centre (UCZ2) are usually from $-0.2 \pm 0.1^{\circ} \mathrm{C}$ to $-0.9 \pm 0.1^{\circ} \mathrm{C}$ cooler, in daily maximum temperature, than immediate surrounding outskirts (UCZ3) which has not been yet described in the literature. This approach is somewhat novel in urban climate studies because it demonstrates significant climate differences between urban climate zones.

\section{References}

Arnfield, A.J., 2003. Two decades of urban climate research: a review of turbulence, exchanges of energy and water, and the urban heat island. International Journal of Climatology 23,1-26.

Baklanov, A., Mestayer, P., Clappier, A., Zilitinkevich, S., Joffre, S., Mahura, A., Nielsen, N.W., 2005. On the parameterisation of the urban atmospheric sublayer in meteorological models. Atmospheric Chemistry and Physics Discussions 5, 12119-12176.

Byrne, G.F., 1979. Remotely sensed land cover temperature and soil water status a brief review. Remote Sensing of Environment 8, 291-305.

Davenport, A.G., Grimmond, S.B., Oke, T.R., Wieringa, J., 2000. Estimating the roughness of cities and sheltered country. In: Proc. 12th AMS Conf. on Applied Climatology, Asheville, North Carolina.

Efron, B., Tibshirani, R., 1993. An Introduction to the Bootstrap. Chapman and Hall, New York, London.
Ellefsen, R., 1990/1. Mapping and measuring buildings in the urban canopy boundary layer in ten US cities. Energy \& Buildings 15-16, 1025-1049.

Eliasson, I., 1996. Urban nocturnal temperatures, street geometry and land use. Atmospheric Environment 30, 379-392.

Gaucherel, C., 2007. Multiscale heterogeneity map and associated scaling profile for landscape analysis. Landscape and Urban Planning 82 (3), 95-102.

Gillespie, A.R., Matsunaga, T., Rokugawa, S., Hook, S.J., 1998. Temperature and emissivity separation from advanced spaceborne thermal emission and reflection radiometer (ASTER) Images. IEEE Transactions on Geoscience and Remote Sensing 36, 1113-1126.

Gillespie, A.R., Rokugawa, S., Hook, S.J., Matsunaga, T., Kahle, A., 2003. Temperature/ emissivity separation algorithm theoretical basis document, Version 2.4. http:// eospso.gsfc.nasa.gov/eos_homepage/for_scientists/atbd/docs/ASTER/atbd-ast-03.pdf.

Gustafson, E.J., 1998. Quantifying landscape spatial pattern: what is the state of art? Ecosystems 1, 143-156.

Johnson, D.P., Wilson, J.S., 2009. The socio-spatial dynamics of extreme urban heat events: the case of heat-related deaths in Philadelphia. Applied Geography 29, 419-434.

Kidder, S.Q., Essenwanger, O.M., 1995. The effect of clouds and winds on the difference in nocturnal cooling rates between urban and rural areas. Journal of Applied Meteorology 34, 2440-2448.

Kłysik, K., Fortuniak, K., 1999. Temporal and spatial characteristics of the urban heat island of Lodz, Poland. Atmospheric Environment 33, 3885-3895.

Kurtz, C., Passat, N., Gancarski, P., Puissant, A., 2010. Multiresolution region-based clustering for urban analysis. International Journal of Remote Sensing 31 (22), 5941-5973.

Leisch, F., 2007. Bootstrap: functions from the book "An Introduction to the Bootstrap", S original, from StatLib and by Rob Tibshirani. R package version 1.0-22. http://www.R-project.org.

Masson, V., 2000. A physically-based scheme for the urban energy budget in atmospheric models. Boundary-Layer Meteorology 94, 357-397.

Masson, V., Gomes, L., Pigeon, G., Liousse, K., Lagouarde, J.P., Voogt, J., Salmond, J., Oke, T., Legain, D., Garrouste, O., Tulet, P., 2008. The canopy and aerosol particles interactions in Toulouse urban layer (CAPITOUL) experiment. Meteorology and Atmospheric Physics 102 (3-4), 135-157.

Mimet, A., Pelissier, V., Quenol, H., Aguejdad, R., Dubreuil, V., Roze, F., 2009. Urbanisation induces early flowering: evidence from Platanus acerifolia and Prunus cerasus. International Journal of Biometeorology, 287-298.

Morris, C.J.G., Simmonds, I., Plummer, N., 2001. Quantification of the influences of wind and cloud on the nocturnal urban heat island of a large city. Journal of Applied Meteorology 40, 169-182.

Nakamura, Y., Oke, T.R., 1988. Wind, temperature and stability conditions in an eastwest oriented urban canyon. Atmospheric Environment 22, 2691-2700.

Ng, E.Y.Y., 2009. Designing High-density Cities for Social and Environmental Suitability. Earthscan, Springer, London, VA.

Nunez, M., Oke, T.R., 1977. The energy balance of an urban canyon. Journal of Applied Meteorology 16, 11-19.

Ohashi, Y., Genchi, Y., Kondo, H., Kikegawa, Y., Yoshikado, H., Hirano, Y., 2007. Influence of air-conditioning waste heat on air temperature in Tokyo during summer: numerical experiments using an urban canopy model coupled with a building energy model. Journal of Applied Meteorology and Climatology 46, 66-81.

Oke, T.R., 1987. Boundary Layer Climates. Methuen, London and New York.

Oke, T.R., 2004. Urban observations, World Meteorological Organization, IOM Report $\mathrm{N}^{\circ} 81, \mathrm{WMO} / \mathrm{TD} \mathrm{n}^{\circ} 1250$. 
Oke, T.R., 2006. Towards better scientific communication in urban climate. Theoretical and Applied Climatology 84, 179-190.

Pigeon, G., Legain, D., Durand, P., Masson, V., 2007. Anthropogenic heat releases in an old European agglomeration (Toulouse, France). International Journal of Climatology 27, 1969-1981.

Prata, A., 1996. A new long-wave formula for estimating downward clear-sky radiation at the surface. Quarterly Journal of the Royal Meteorological Society $122,1127-1151$.

R Development Core Team, 2008. R: A Language and Environment for Statistical Computing. R Foundation for Statistical Computing, Vienna, Austria, ISBN 3900051-07-0. http://www.R-project.org.

Ren, C., Ng, E.Y.Y., Katschner, L., 2010. Urban climatic map studies: a review. International Journal of Remote Sensing. http://dx.doi.org/doi:10.1002/joc.2237 (online)

Roth, M., Oke, T.R., Emery, W., 1989. Satellite-derived urban heat islands from three coastal cities and the utilization of such data in urban climatology. International Journal of Remote Sensing 10, 1699-1720.

Schroeder, A.J., Basara, J.B., Illston, B.D., 2010. Challenges associated with classifying urban meteorological stations: the Oklahoma City Micronet example. Open Atmospheric Science Journal 4, 88-100.
Stewart, I.D., Oke, T.R., 2009a. Newly developed “thermal climate zones" for defining and measuring urban heat island magnitude in the canopy layer. Preprints, Eighth Symposium on Urban Environment, January 11-15, Phoenix, AZ.

Stewart, I.D., Oke, T.R., 2009b. Classifying urban climate field sites by "local climate zones": the case of Nagano, Japan. Preprints, Seventh International Conference on Urban Climate, June 29-July 3, Yokohama.

Stewart, I.D., Oke, T.R., 2010. Thermal differentiation of local climate zones using temperature observations from urban and rural field sites. Preprints, Ninth Symposium on Urban Environment, August 2-6, Keystone, CO.

Szymanowski, M., 2005. Interactions between thermal advection in frontal zones and the urban heat island of Wroclaw, Poland. Theoretical and Applied Climatology 82, 207-224.

Voogt, J.A., Oke, T.R., 2003. Thermal remote sensing of urban climates. Remote sensing of Environment 86, 370-384.

Weng, Q., Quattrochi, D.A., 2006. Thermal remote sensing of urban areas: an introduction to the special issue. Remote Sensing of Environment 104 119-122.

Wu, J.G., Shen, W.J., Sun, W.Z., Tueller, P.T., 2002. Empirical patterns of the effects of changing scale on landscape metrics. Landscape Ecology 17, 761-782. 